\title{
難聴学級児童の言語力の経年的観察 $(2)$
}

一作文能力の経年的変化—

\author{
小林はるよ 田中美 郷
}

\begin{abstract}
要 約 : 15 名の難聴学級児童に対し， 3 年以上の期間にわたり（最終検査学年は，小学 5 年以 上), 1 年に 1 回, 5 枚のストーリーをもった絵についての話を書かせるといら同一の課題で作 文 検査を実施，作文能力の経年的変化を検討した．その結果，

1. 難聴児の作文能力には学年の上昇に伴ら発達がみられるが，健聴児と比較すると，文法的側 面でとくに劣っている.

2. 難聴児の, 同学年のあいだでの作文能力の順位は, 学年が上昇しても, あまり変動しない.

3. 作文能力の経年的変化には, 読書力, 平均聴力レベルにより, 異なる特徵がみられる. ことを示し, 就学前期, 小学低学年までの言語獲得の重要性および言語力, 聴力を考虑した作文指 導の必要を指摘した.
\end{abstract}

索引用語 : 難聴学級児童, 作文能力, 経年的变化, 早期教育

\author{
Progress in Linguistic Abilities in Hearing-impaired Children (2) \\ The Development of Writing Skills \\ Haruyo Kobayashi and Yoshisato Tanaka
}

\begin{abstract}
We studied the development of writing skills in 15 hearing-impaired children who were integrated in regular primary schools and received part-time therapy. Their achievements were compared with those of children with normal hearing.

The hearing level of the subjects was $89.9 \mathrm{~dB}$ on the average. They showed an average grade placement gap of almost a year in reading ability in the sixth grade.

The subjects were assessed for their writing skills once a year over a period of more than three years. The test required the subjects to write a composition about what they observed in a series of pictures. The results were as follows :

1. Writing skills improved as school grade and reading ability levels got higher, though difficulties varied according to the degree of hearing loss and reading ability.

2. The good writers in early grades were the good writers in higher grades and vice versa.

We concluded that, for good development of writing skills, language acquisition during early grades was very important, and to improve the writing skills of hearing-impaired children individual approaches were needed.
\end{abstract}


Key words : Hearing-impaired Children, Writing Skills, Linguistic Abilities in Hearingimpaired, Early Education

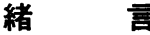

難聴児の作文能力については，語い，文法などそのさ まざな側面で，同年龄の健聴児より劣っている，とされ ている ${ }^{1 \sim 3)}$. わが国の研究にも, 同一の課題で書いた作 文を難聴児と健聴児の間で比較したもの ${ }^{4,5}$, 特定の 難 聴児の作文能力の発達を検討したもの ${ }^{6)}$, 文法の誤りに ついて分析したもの ( ) 訓練方法について検討したもの $^{8)}$ などがある. 本報告では, 同一の症例が，数年にわたっ て同一課題で書いた作文について，学童期の難聴児の作 文能力の経年的变化の特徵, 作文能力の伸びの比較, 抒 よび, それらに関与する聴力, 読書力, 訓練開始時期な どの要因について検討を試みた。

\section{対象}

対象は堀内ら ${ }^{9)}$ の扱ったものと同じで，東京都内難聴 学級 (小学校 3 学級) に在籍する難聴児である. ただし 本論文で扱った難聴児は 3 年以上にわたって作文力検査 を実施しえた, 最終検査学年が小学校 5 年以上である 15 名である. 対象群の聴力レベルの平均は 89.9dB (S. D. $15.3 \mathrm{~dB})$ である. 対照群として, 都内の某区立小学校の 2 年, 4 年, 6 年の同一学級の生徒 (男子) の名簿の前 から順に，それぞれ10名，10名，9名に同じ検査を実施 し，結果を比較検討した。

\section{方法}

作文検查は, 国立国語研究所が昭和34年に実施した検 査 ${ }^{10)}$ と同じもので，図1のような 5 枚の絵を見せなが ら，作文を書かせた．指示を口頭で与えた後, 絵の横に 「絵を見て, 楽しい括話をつくってください.」と書か れた文を読ませて理解させた，制限時間は設けなかっ た.この検査を年 1 回, 難聴学級児童が来院して実施す る定期検診のさいに行った。（本報告の(1)参照）

以上のようにして書かれた作文について，以下の $3 つ$ の尺度によって評価した．第1は作文が単なる絵の説明 から，書き手が想像を加えて構成する物語へと発展する 内容的な側面を評価する尺度として，作文中に使用され た文節数の総数である. 第 2 に文法能力の側面を評価す る尺度として表記の誤りを除く，語い，文法上の明白な 誤りを含む文の，文総数にたいする割合をみた．第 3 に，認識的な側面を評価する尺度として，絵の説明に必 要な要素が記述できている割合をみた。

絵の説明に必要な要素としては, 以下の文の下線の部
分を，必要な要素とし，不正確です，意味的に言及して いると認められる表現があれば，記述されているものと みなした。

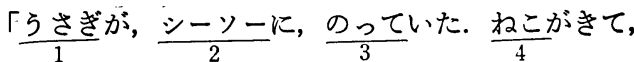
シーソーの反対側にのると, シーソーが, つり合った (上下した). 犬がきて， ねこの後にのると，尖さぎが

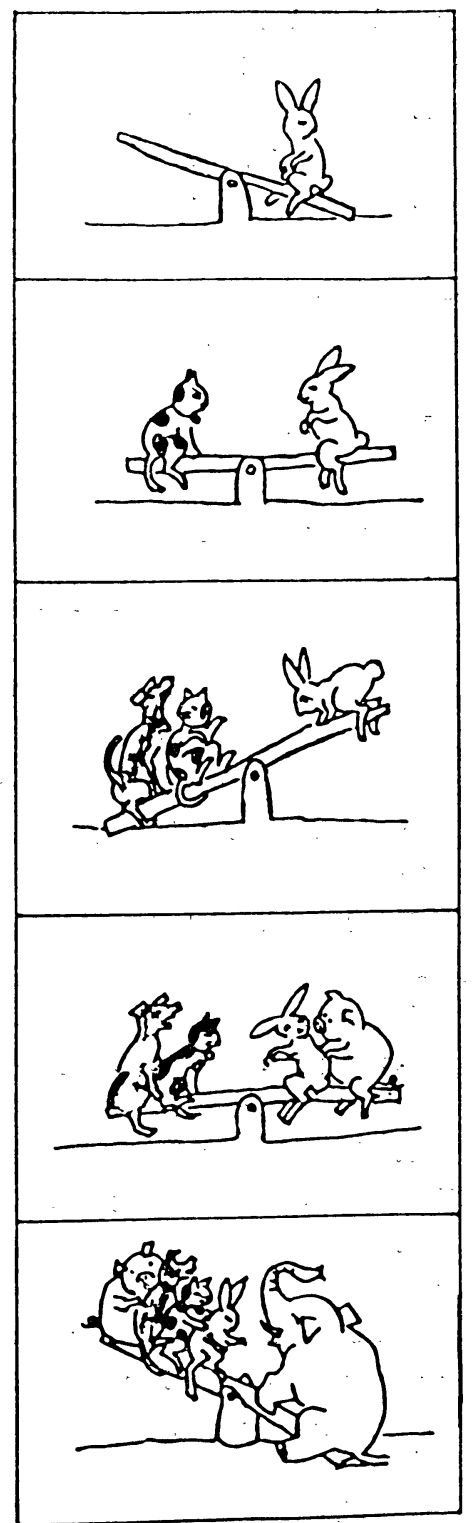

図 1 作文検查に用いた絵 
上がってしまった. ぶたがきて， 战ざの後にのると，

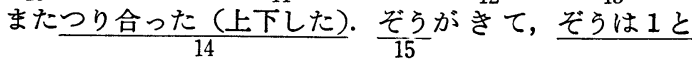

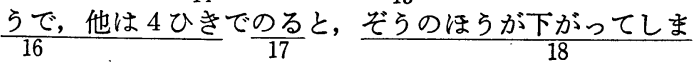
つた.」

この基準では必要な要素数は18となり, 登場動物の名 しか書けていない場合には，記述できた要素数は 5 とな り, 割合は $5 / 18,28 \%$ となる.

つぎに，作文能力の伸びを比較するために，同学年の 中で作文能力に段階をつけ，それが学年の上昇とともに

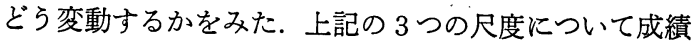
がその学年の中央値以上である場合と中央値未満である 場合とに分け，3つの尺度全部で成績が中央值以上であ る場合を段階 $\mathrm{A} ， 2$ つの尺度で成績が中央值未満である 場合を B とし，1つの尺度において成績が中央值以上で 2 つの尺度において中央値未満である場合を C，3つの 尺度全部において成績が中央値未満である場 合を D と し，検査学年ごとに作文能力を $\mathrm{A}$ から Dのいずれかの段 階に評価した，以下，本報告では，対象児が15名で，成 績のばらつきが大きいので, 代表值としては中央値を採 用した。

\section{結果}

はじめに作文能力の群全体としての経年变化を検討し た. 図 2 は, 文節数の総数の推移を学年ごとの中央值で 示したもので, 実線は対象児群の, 1 点破線は対照群の 成績を示している．綐の細い線は同学年の最小值から最 大值までを示し，太い縦の線は中央値を中心として全体 の50\%の症例の成績の範围を示している. 文節数は学年 の上昇とともに增加するが，最大値と最小值の差も増加 する傾向が認められる. 対照群と比較すると, 対照群の ほうが，どの学年においても，成績が良いが，50\%の範

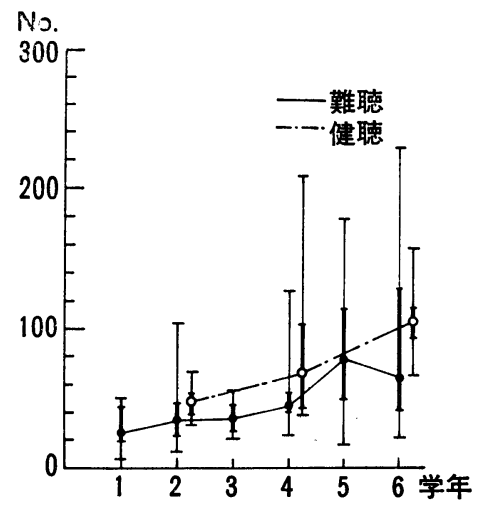

図 2 文節数の推移

細い線は, 最小値と最大値の範囲, 太い線は $50 \%$ 範囲, 両群の間には, 有意差がない.

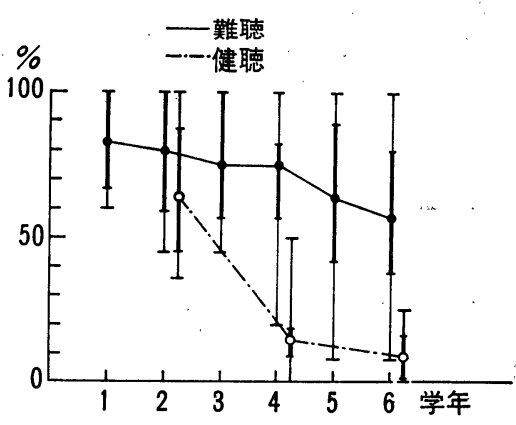

図 3 誤り文の割合の推移 細い線は, 最小值と最大值の範囲, 太い線は, $50 \%$ の範囲, 両群の間汇は, 4 年と 6 年で有 意差がある。

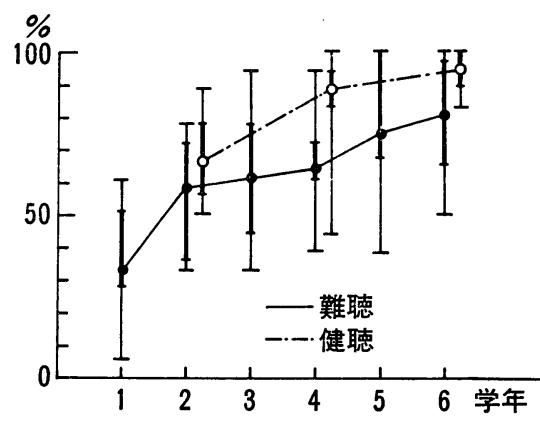

図 4 必要な要素の記述の割合の推移 細い線は最小值と最大值の範囲, 太い線は50 \%の範囲, 両群の間には, 4 年で有意差があ る.

团は重なっており，Uテスト検定をすれば，両群の間に はどの学年においても有意な差がない，

図 3 は, 誤り文の文総数に対する割合の推移を学年ご との中央値で示している，学年の上昇に伴い，誤り文の 割合は減少しているが，6年になっても中央值は $59 \%$ で ある. 対照群と比較すれば, 2 年では両群の間に有意な 差がないが, 4 年では $\mathrm{p}<0.001,6$ 年でも $\mathrm{p}<0.001 て ゙$, いずれる有意差がある.

図 4 は必要な要素が記述されている割合の推移を学年 ごとの中央值で示している. 学年の上昇とともに群全体 として成績が向上する傾向がみとめられる. しかし成績 は対照群のほうが良く, 4 年では両群の間に $\mathrm{P}<0.01$ で 有意差があり, 6 年では対照群に比べ最大值と最小值の 差が大きい。

つぎに，図 5 に個々の症例について初回検查学年と最 終検査学年の成績の段階がぞう变動したかを示した．初 回検查学年と最終検査学年での段階が $\mathrm{A} \rightarrow \mathrm{A}$ のように同 
じである場合が15名中 7 名，BＣCのように 1 段階変動 した場合が 7 名, 1 名のみ $\mathrm{A} \rightarrow \mathrm{D}$ と下降した. 全体とし て. 同学年の中での相対的な評価には大きな変動がな

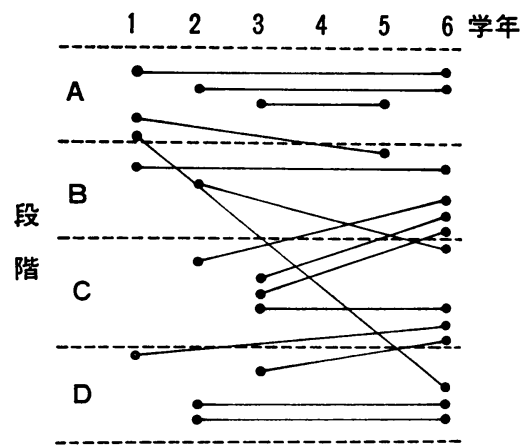

図 5 相対的評価の変動

変動なし 7 名, 1 段階の変動 7 名, 3 段階の 変動 1 名
く，低学年で成績が良いと高学年でも良く，逆に低学年 で悪いと高学年でも悪い，といら傾向がみとめられた。

图 6 には，最終検查学年の成績の段階ごとに対象児を 4 群に分け，個々の症例の経年的変化を示した． 右下は 段階Dの 3 名で，ぞの尺度においても成績はほとんど横 ばいである．点線は，対象児群の中央值を示す．左下は 段階Cの 4 名で，ぞの尺度において子経年的変化の幅が 少なく，必要な要素の脱落が多い症例が目立つ．右上は 段階 $\mathrm{B}$ の 5 名であるが，文節数の伸びが著しいが誤り文 の克服が困難な傾向がみとめられる．また文節数が多い のに必要な要素の脱落が多い症例もある. 左上は段階 $\mathrm{A}$ の 3 名で, 誤り文が高学年で急激に減少しており, 必要 な要素の脱落は一貫して少ないが，文節数の伸びは段階 Bほど著しくない。
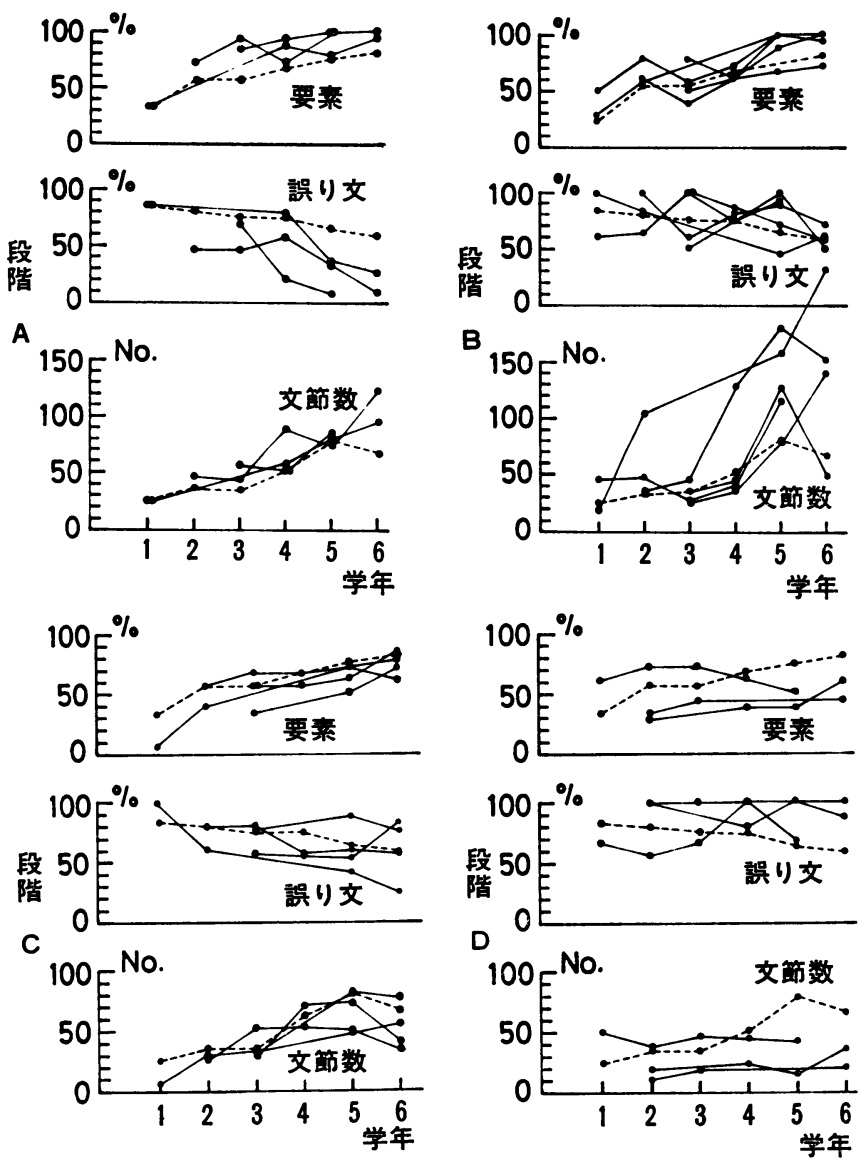

图 6 段階ごとの経年的変化

点線は, 対象児群全体の中央值. 段階 $\mathrm{B}$ は, 文節数の伸びが著しい. 段階 $\mathrm{D}$ は, 成績の経年的変化が少ない。 


\section{考察}

はじめに本報告で採用した作文評価の 3 つの尺度につ いて考察する. 国立国語研究所の調查では, 内容的な発 展を示す指摘のなかに, 会話が使用されているか否か と, 情景描写一登場動物の「性別, 名前, 性格づけ, 動 作，表情などに着眼して表現しているか」が，あげられ ている ${ }^{10)}$. そこで文節数とこれらの指標との関連をみる と, 会話が表現されている作文のらち, もっとも文節数 が少ない場合は48で，文節数が 85 以上の作文では10例全 部に会話が表現されていた. 情景描写については文節数 が57からあり，文節数79以上の作文13には全例にみられ る. すなわち文節数が多くなれば，物語としての内容を そなえてきて，書き手の想像によって書かれる部分が増 す，といえる.

了解不能な意味不明文は 1 年では䛊り文の割合 $83 \%$ 中 の $40 \%$ であるが， 6 年では $59 \%$ 中の $6 \%$ である. 学年の 上昇とともに意味不明文は，語い，文法などの部分的な 誤りを含む文にかわり，䛊りを含む文の割合は緩かに減 少する.すなわち誤り文の割合の内容は, 学年によって 異なる，また，正しい文には簡単な文が多く，複雑な文 には誤り文が多くなる ど) という傾向もみられる。したが って誤りを含む文の割合といら尺度は, 文法能力の学年 間の厳密な比較には適当でないが, 少なくとも同学年の 間では比較の尺度となろう．たとえば 6 年では誤りを含 む文の割合が中央值の $59 \%$ 以上である 6 例全例に意味不 明文があり，中央值未満である 6 例にはなく，誤りを含 む文の割合が中央值未満から $26 \%$ の間では 2 箇所以上の 誤りを含む文があり，8\%の1例では，1つの文の中に 1 籄所のみの誤り, といら誤り文しかない。

つぎに必要な要素数の記述の割合が, 群全体として増 加する傾向がみられることは, 内容や文法的な側面での 改善が著しくない症例に㨟いても, 必要な要素は学年の 上昇とともに書き表されるようになることを意味する。 「難聴児には，語りたい内容がたくさんあるのに，文法 体系が十分身についていないために（中略）文として整

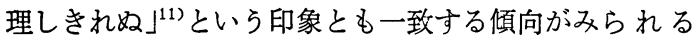
といえよう。

対象児群と対照群を比較すれば, 物語を構成するとい ら側面では, 対象児群にも対照群に近い発達を遂げる症 例が約半数いるが，その内容を脱落なく，正しく表現す るといら側面では対照群との差が大きく，3つの尺度全 部で, 対照群の成績の $50 \%$ の範囲に入るのは, 高学年 15 名中 1 ～2名となる.

つぎに, 作文能力の発達に影響する要因について考察 する. 最終検査学年に拈ける評価段階ごとに症例を比較

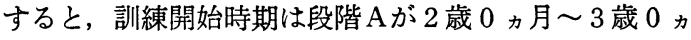
月, $\mathrm{B} か ゙ 1$ 歳 6 力月から 5 歳 1 力月, $\mathrm{C}$ が 2 歳 0 力月〜 4 歳 0 力月, $\mathrm{D} か ゙ ~ 2$ 歳 6 カ月〜 4 歳 0 力月で, $\mathrm{D} か ゙$ 全体 として遅いが，明白な傾向は見い出し難い。平均聴力レ ベルは段階 $\mathrm{A} か ゙ 95 〜 103 \mathrm{~dB} ， \mathrm{~B} か ゙ 73 〜 95 \mathrm{~dB} ， \mathrm{C} か ゙ 76 〜 96$

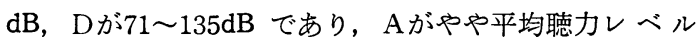
が重い. 初回検查学年の読書力検查の偏差值は, 段階 $\mathrm{A}$ が38〜 56, Bが39〜 59, Cが38〜 47, Dが31〜49, 最終 検查学年では段階 Aが 39〜 56, Bが 37〜 53, Cが 42〜 45, Dが26〜39で，A，Bには差がなく，Cには，偏差 值が高い症例がなく，Dは低い，PIQ には段階 Aから D まで高い症例が多く差がない。

読書力検查偏差值は段階 $\mathrm{A}, \mathrm{B}$ に差がなく, C, Dが 低く, 作文能力評価との相関がみられるが, 個々の症例 をみれば偏差值が 40 前後でも相対的に高い評価を得る場 合もあり, 必ずしも一致しない. 段階 A, B の間に読書 力検査偏差值の差がなく, 平均聴力レベルはAのほうが 重いことを考光ると， A， Bの作文能力には，差がある といらよりも，傾向の違いがあるとみたほうが適当かも しれない. 段階 Bには, 文節数の伸びが著しいのに, 誤 り文や必要な要素の脱落がみられ，Aには誤り文や必要 な要素の脱落が少ないが，文節数の伸びは著しくない. したがってA，Bのいずれにも, 豊富な内容を正しく記 述するといら課題が残されているといえよう. そして, $\mathrm{A}, \mathrm{B}$ の以上のような傾向の差には, 平均聴力レベルの 違いが反映されている可能性があり, 指導の上からは, このような違いに応じた配慮が必要であろう。

堀内ら の) の報告では, 低学年で読書力検査成績が良い 症例は高学年でも良い場合が多く, 成績に大きな変動が なかった．本報告における作文能力の評価でも同じ傾向 があることを指摘したい. 以上の結果は, 文章力の調査 で, 低学年での個々の生徒の傾向が高学年にもちこされ る(2)とした, 犝学校での結果とも一致している. 早期教 育, 就学前期の言語獲得の重要性は, 堀内ら ${ }^{9)}$ および著 者らの示した学童期の言語発達の 1 側面の分析からも確 認されると考光る.ただし, 読書力検査成績に拈いて も, 作文能力の評価においても, 低学年で比較的高かっ たのに伸び悩んだきわめて高度な難聴を有する症例があ ること, 平均聴力レベルの違いが作文の傾向に影響して いると考兄られることから, 難㯖学級児童の言語発達に は, 平均聴カレベルの影響も無視できない.

最後に, 本報告と同じ課題を用いて韵学校在籍児の作 文能力を分析した「作文にみる聴覚障害児の言語能力の 発達」4) と, 本報告の場合を比較すると, 本報告では, 一方的呼びかけではない会話が記述されている割合が, 6 年の 12 名中 8 名, $67 \%$ で槊学校調査の $37.5 \%$ を上回っ 
ている．情景描写や，重さ比べをとりあげているなどの 指標に関しては, 差がない. 会話の記述の多さに関して は, 本報告の対象児が, 難聴学級在籍児であることの影 響が考えられよう。

\section{ま と め}

15 名の難聴学級児童に対し， 3 年以上の期間にわたり (最終検査学年は小学 5 年以上), 1 年に 1 回, 5 枚の, ストーリーをもった絵てついての話を書かせるという同 一の課題で作文検查を実施, 作文能力の発達をみた。難 聴児の作文能力は，学年の上昇とともに発達している が, 文法的側面では, 中学年以上で, 健聴児の成績との あいだに差がみられた。 また，小学校低学年で作文能力 の成績の良い症例は高学年でも良く, 順位の変動が少な い傾向があった．作文能力の経年的变化には, 読書力, 聴力との関係がみとめられた. 以上の結果により, 低学 年までの言語獲得の重要性, 作文能力の特徵を考虑した 指導の必要を指摘した。

資料の收集, 検査にご協力くださった帝京大学医学部耳鼻咽 喉科小児難聴言語外来の, 広田栄子さん, 堀内美智子さんに深 謝いたします。

\section{文献}

1) Myklebust, H. R. : The Psychology of Deafness. Grune \& Stratton, 1964.

2) Kretshmer and Kretshmer: The Perspective in Audiology Series, Language Devəlopment and Intervention with the Hearing Impaired. University Park Press.
3) Crandall, K. E. : Reading and Writing Instruction for Deaf Young Adults; Deafness and Communication. Williams \& Wilkins, 1982.

4 ) 今西伊都子：作文にみる聴覚障害児の言語能力の発 達. 万う教育科学, 26(4) : 193-197, 1984.

5 ) 松本末男, 他 : 聴覚障害児の絵画題材への読み取り 能力が作文へ及ぼす影響について。聴覚障害, 10 (367) : 4-13, 1981.

6 ）川井，潤：聴覚障害児の書きことば(1)一日記による 縦断的研究 (その 1). 万5.教育科学, 12(1) : 1-17, 1970.

7 ) 竹村 茂 : 聴覚障害児の日記指導一表現の誤りを中 心に. 筑波大学附属竩学校紀要, $3: 9-20,1981$.

8 ）坂本多朗 : 文章表現の誤りをどう指導したか(III). 聴覚障害, $35: 10-18,1980$.

9 ) 堀内美智子 : 難聴学級児童の言語力の経年的観察一 (1)読書力の経年的变化. 音声言語医学, 27(3) :223228, 1986.

10）国立国語研究所 : 小学生の言語能力の発達. 明治図 書, 1965.

11）伊藤恵美 : 作文能力の発達の一側面 (その 3 ). 聴 覚障害, 5 (350) : 31-38, 1980.

12）山本隆三 : 聴覚障害児の文章表現について一文章完 成法テストの結果を中心として一. 筑波大学教育学 部附属壟学校紀要, $1(1): 71-84,1979$.

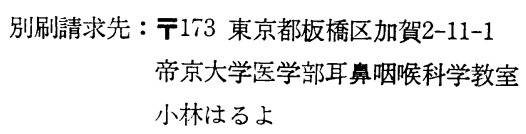

